\title{
Association of machine learning-derived measures of body fat distribution in $>40,000$ individuals with cardiometabolic diseases
}

\author{
Saaket Agrawal, $\mathrm{BS}^{1,2,3^{*}}$, Marcus D. R. Klarqvist, $\mathrm{PhD}^{4^{*}}$, Nathaniel Diamant, BS ${ }^{4}$, \\ Patrick T. Ellinor, MD, PhD ${ }^{1,3}$, Nehal N. Mehta, $\mathrm{MD}^{5}$, Anthony Philippakis, MD, PhD ${ }^{4,6}$, \\ Kenney Ng, PhD ${ }^{7}$, Puneet Batra, $\mathrm{PhD}^{4}$, Amit V. Khera, $\mathrm{MD}^{1,2,3}$
}

\section{Author Affiliations}

1) Cardiovascular Disease Initiative, Broad Institute of MIT and Harvard, Cambridge, MA

2) Center for Genomic Medicine, Department of Medicine, Massachusetts General Hospital, Boston, MA

3) Department of Medicine, Harvard Medical School, Boston, MA

4) Data Sciences Platform, Broad Institute of MIT and Harvard, Cambridge, MA

5) National Heart, Lung, and Blood Institute, National Institutes of Health, Bethesda, MD

6) Eric and Wendy Schmidt Center, Broad Institute of MIT and Harvard, Cambridge, MA

7) Center for Computational Health, IBM Research, Cambridge, MA

*Mr. Agrawal and Dr. Klarqvist contributed equally to this article.

\section{Please address correspondence to:}

Amit V. Khera, MD, MSc

Center for Genomic Medicine

Massachusetts General Hospital

185 Cambridge Street

Simches Research Building | CPZN 6.256

Boston, MA 02114

Tel: 617.726 .7876

Email: avkhera@mgh.harvard.edu 
medRxiv preprint doi: https://doi.org/10.1101/2021.05.07.21256854; this version posted May 10, 2021. The copyright holder for this preprint (which was not certified by peer review) is the author/funder, who has granted medRxiv a license to display the preprint in perpetuity.

All rights reserved. No reuse allowed without permission.

\begin{abstract}
Background

Obesity is defined based on body-mass index (BMI), a proxy for overall adiposity. However, for any given BMI, individuals vary substantially in fat distribution. The clinical implications of this variability are not fully understood.
\end{abstract}

\title{
Methods
}

We studied MRI imaging data of 40,032 UK Biobank participants. Using previously quantified visceral (VAT), abdominal subcutaneous (ASAT), and gluteofemoral (GFAT) adipose tissue volume in up to 9,041 to train convolutional neural networks, we quantified these depots in the remainder of the participants. We derived new metrics for each adipose depot - fully independent of BMI - by quantifying deviation from values predicted by BMI (e.g. VAT adjusted for BMI, VATadjBMI) and determined associations with cardiometabolic diseases.

\section{Results}

Machine learning models based on two-dimensional projection images enabled near-perfect estimation of VAT, ASAT, and GFAT, with $r^{2}$ in a holdout testing dataset $>0.97$ for each. Using the newly derived measures of local adiposity - residualized based on $\mathrm{BMI}$ - we note marked heterogeneity in associations with cardiometabolic diseases. Taking presence of type 2 diabetes as an example, VATadjBMI was associated with significantly increased risk (odds ratio per standard deviation increase (OR/SD) 1.49; 95\% Cl: 1.43-1.55), while ASATadjBMI was largely neutral (OR/SD 1.08; 95\%Cl: 1.03-1.14) and GFATadjBMI conferred protection (OR/SD 0.75; 95\%Cl: 0.71-0.79). Similar patterns were observed for coronary artery disease. 
medRxiv preprint doi: https://doi.org/10.1101/2021.05.07.21256854; this version posted May 10, 2021. The copyright holder for this preprint (which was not certified by peer review) is the author/funder, who has granted medRxiv a license to display the preprint in perpetuity.

All rights reserved. No reuse allowed without permission.

\section{Conclusions}

For any given BMI, measures of local adiposity have variable and divergent associations with cardiometabolic diseases. 
medRxiv preprint doi: https://doi.org/10.1101/2021.05.07.21256854; this version posted May 10, 2021. The copyright holder for this preprint (which was not certified by peer review) is the author/funder, who has granted medRxiv a license to display the preprint in perpetuity.

All rights reserved. No reuse allowed without permission.

\section{INTRODUCTION}

Obesity is a leading threat to global public health, with afflicted individuals at increased risk of a broad range of poor health outcomes - cardiovascular events, type 2 diabetes, cancer, and severe COVID-19 infection..$^{1-3}$ Recent projections suggest that obesity - defined within clinical practice solely on the basis of body mass index (BMI) of at least $30 \mathrm{~kg} / \mathrm{m}^{2}$ - will affect more than half of the U.S. adult population by as early as $20300^{4,5}$

Although individuals with increased BMI tend to have higher risk of adverse outcomes on average, previous studies have suggested considerable heterogeneity. ${ }^{6-9}$ These studies have sought to define markers of 'metabolic health' that can modify risk of obesity or nominated additional anthropometric measurements - such as measures of insulin resistance or waist circumference - as drivers of "within BMI-group variation" in cardiometabolic risk. ${ }^{9-11}$

Variation in fat distribution is a potential unifying explanation of cardiometabolic risk differences between two individuals of a given BMI. ${ }^{12,13}$ Prior seminal studies have suggested that various fat depots have differing metabolic programs, with visceral adipose tissue (VAT) most strongly associated with cardiometabolic risk - but have potential limitations. ${ }^{14-16}$ First, most imaging studies to date have been cross-sectional and relatively small - especially those utilizing the gold-standard MRI modality - limiting ability to assess for depot-specific effects across age, sex, and BMI subgroup demographics. ${ }^{12,17-21}$ Second, gluteofemoral adipose tissue (GFAT), which may serve as an adaptive energy storage depot and a possible modifier of insulin resistance, has not been quantified by MRI in most previous studies. ${ }^{18-22}$ Third, fat depot volumes tend to be highly correlated with both BMI and each other, making it challenging to isolate depot-specific associations with disease. ${ }^{23}$

In this study, we downloaded raw MRI imaging data from 40,032 participants of the UK Biobank and used machine learning models to precisely measure three fat depot volumes: VAT, abdominal 
medRxiv preprint doi: https://doi.org/10.1101/2021.05.07.21256854; this version posted May 10, 2021. The copyright holder for this preprint (which was not certified by peer review) is the author/funder, who has granted medRxiv a license to display the preprint in perpetuity. All rights reserved. No reuse allowed without permission.

subcutaneous adipose tissue (ASAT), and GFAT. We derive new measures for local adiposity burden, each fully independent of BMI and note significant heterogeneity in risk conferred: VAT adjusted for BMI (VATadjBMI) associated with increased risk of type 2 diabetes and coronary artery disease, ASATadjBMI largely risk-neutral, and GFATadjBMI conferring protection. 
medRxiv preprint doi: https://doi.org/10.1101/2021.05.07.21256854; this version posted May 10, 2021. The copyright holder for this preprint (which was not certified by peer review) is the author/funder, who has granted medRxiv a license to display the preprint in perpetuity.

\section{METHODS}

\section{Study population}

The UK Biobank is an observational study that enrolled over 500,000 individuals between the ages of 40 and 69 years between 2006 and 2010, of whom 43,521 underwent MRI imaging between 2014 and 2020 as part of an imaging substudy. ${ }^{24,25}$ After exclusion of 3,489 (8.0\%) imaging scans based on technical problems or artifacts, 40,032 participants remained available for analysis (Supplementary Appendix). This analysis of data from the UK Biobank was approved by the Mass General Brigham institutional review board and was performed under UK Biobank application \#7089.

Machine learning to measure fat depot volumes

Among the 40,032 individuals with MRI imaging data available, a subset had visceral adipose tissue (VAT) volume, abdominal subcutaneous adipose tissue (ASAT) volume, and total adipose tissue (TAT) volume between the top of vertebrae T9 and the bottom of the thigh muscles, quantified and made available as previously described ( $N=9,040,9,041,7,754$ participants, respectively). ${ }^{20,21,26,27}$

Gluteofemoral adipose tissue (GFAT) volume was derived by computing the difference between TAT and the sum of VAT and ASAT (Supplementary Appendix). We quantified these fat depots in the remaining participants using machine learning models, trained on composite images for each individual comprised of coronal and sagittal two-dimensional projections of both the fat and water phases (Figure 1). Individuals with previously quantified volumes were randomly split into $80 \%$ for convolutional neural network (CNN) training and cross-validation and a 20\% holdout sample for testing (Table S1). Each CNN was then used to quantify the volume of the corresponding fat depot in the remaining individuals. More comprehensive descriptions of the deep learning modeling and quality control - and the open-source code repository for data ingestion - are provided in the Supplementary Appendix. 
medRxiv preprint doi: https://doi.org/10.1101/2021.05.07.21256854; this version posted May 10, 2021. The copyright holder for this preprint (which was not certified by peer review) is the author/funder, who has granted medRxiv a license to display the preprint in perpetuity. All rights reserved. No reuse allowed without permission.

\section{Cardiometabolic disease definitions}

The primary outcomes were prevalent and incident type 2 diabetes and coronary artery disease, where incident disease was defined as occurring after the date of MRI. Type 2 diabetes was defined on the basis of ICD-10 codes, self-report during a verbal interview with a trained nurse, use of diabetes medication, or a glycated hemoglobin greater than or equal to $6.5 \%$ before the date of imaging (Table S3). Coronary artery disease was defined as myocardial infarction, angina, coronary revascularization, or death from coronary causes as determined on the basis of ICD-10 codes, ICD-9 codes, OPCS-4 surgical codes, nurse interview, and national death registries (Table S4).

\section{Statistical analysis}

We generated BMI-adjusted fat depot measurements by computing residuals from sex-specific linear regression models using $\mathrm{BMI}$ as the predictor and fat depot volume as the outcome, analogous to prior studies of waist-hip ratio adjusted for $\mathrm{BMI}^{28,29}$ Logistic regression models were used to test the association of BMI-adjusted fat depot measurements with prevalent disease. To compute odds ratios across age, sex, and BMI subgroups, models were adjusted for age, sex (except in sex subgroup analyses), BMI, the other two fat depots (e.g. ASATadjBMI and GFATadjBMI for VATadjBMI), and MRI imaging center. Cox proportional-hazard models with the same covariates were used to test associations of BMI-adjusted fat depots with incident type 2 diabetes and coronary artery disease events. Finally, we used sex-stratified logistic regression to determine the gradient in probability of prevalent disease across clinical BMI categories. These models included interaction terms with body mass index along with the previously noted covariates and were standardized to the median of all predictor variables (except for MRI imaging center variable, where the mean was used) within each population. ${ }^{4}$

All analyses were performed with the use of R software, version 3.6.0 (R Project for Statistical Computing). 
medRxiv preprint doi: https://doi.org/10.1101/2021.05.07.21256854; this version posted May 10, 2021. The copyright holder for this preprint (which was not certified by peer review) is the author/funder, who has granted medRxiv a license to display the preprint in perpetuity.

All rights reserved. No reuse allowed without permission.

\section{RESULTS}

Among 40,032 participants with MRI data available, the mean age was 65 years, $51 \%$ were women, and $97 \%$ were white (Table 1). Mean BMI was $26.1 \mathrm{~kg} / \mathrm{m}^{2}$ among women and $27.1 \mathrm{~kg} / \mathrm{m}^{2}$ among men, and mean waist-hip ratio (WHR) was 0.82 among women, and 0.94 among men. 1,901 individuals had been diagnosed with type 2 diabetes (4.7\%) and 1,956 with coronary artery disease (4.9\%) at the time of imaging assessment.

Machine learning facilitates near-perfect estimation of fat depot volumes

To train convolutional neural network models to measure VAT, ASAT, and GFAT, we first simplified the three-dimensional MRI images into composite two-dimensional projections of coronal and sagittal views, leading to an 830-fold reduction in data input size (Figure 1). These machine learning models trained on $80 \%$ of the participants with fat depots previously quantified - demonstrated near-perfect estimation association of each fat depot in the $20 \%$ of remaining individuals for each depot $\left(r^{2}=0.991\right.$, 0.991, and 0.978 for VAT, ASAT, and GFAT, respectively), with similar predictive accuracy noted across male and female participants and in the small subset of non-White participants (Figure S1). These convolutional neural network models were subsequently applied to the remainder of the 40,032 participants to calculate fat depot volumes.

Variation in adipose volumes and association with cardiometabolic diseases

We confirm and extend prior evidence for marked differences in fat depot volume in men versus women (Figure 2A). ${ }^{30,31}$ Mean visceral adipose tissue volume was substantially higher in men as compared to women -5.0 versus 2.6 liters, respectively - while abdominal subcutaneous and gluteofemoral depots tended to predominate in women (Table 1). Moderate strength of correlation between global adiposity as assessed by BMI and all three fat depots was noted-Pearson $r$ ranging 
medRxiv preprint doi: https://doi.org/10.1101/2021.05.07.21256854; this version posted May 10, 2021. The copyright holder for this preprint (which was not certified by peer review) is the author/funder, who has granted medRxiv a license to display the preprint in perpetuity. All rights reserved. No reuse allowed without permission.

from 0.77 to 0.91 - but considerable variation was observed within any clinical BMI category (Figure 2A-

B).

Adipose tissue volumes were each associated with increased prevalence of cardiometabolic diseases - as might be expected based on strength of correlation with BMI - with risk gradient most pronounced for VAT. Taking type 2 diabetes as an example, odds ratios per standard deviation increment (OR/SD) were $2.14(95 \% \mathrm{Cl} 2.05-2.23), 1.69(95 \% \mathrm{Cl} 1.63-1.75)$, and $1.48(95 \% \mathrm{Cl} 1.42-1.54)$ for VAT, ASAT, and GFAT, respectively (Table S5).

BMI-adjusted local fat depots and cardiometabolic disease

To disentangle the unique impact of each fat depot from overall BMI, we next generated new measurements of VATadjBMI, ASATadjBMI, and GFATadjBMI for each participant by computing sexspecific BMI residuals in 38,680 (97\%) of the study population with BMI measurement on the day of MRI imaging available. These residuals reflect the difference in an individual's local adipose tissue volume as compared with that expected based on BMI. These metrics were fully independent of BMI and largely independent of anthropometric measures and each other (Figures S2-S3).

In contrast to analysis of raw tissue volumes - where each depot was associated with increased risk - significant heterogeneity was noted for BMI-adjusted values. In a mutually adjusted logistic regression model, we observe that VATadjBMI was associated with increased prevalence of type 2 diabetes OR/SD 1.49; 95\% Cl 1.43-1.55). By contrast, a largely neutral effect estimate was noted for ASATadjBMI (OR/SD 1.08; 95\%Cl 1.03-1.14) and GFATadjBMI volumes were associated with decreased risk (OR/SD 0.75; 95\% Cl: 0.71-0.79) (Figure 3). Effect estimates were largely consistent in subgroups binned by age or sex, with mildly attenuated gradients among participants with obesity (Figure S4-S5). A similar pattern was observed for coronary artery disease, where associations for VATadjBMI, ASATadjBMI, and 
medRxiv preprint doi: https://doi.org/10.1101/2021.05.07.21256854; this version posted May 10, 2021. The copyright holder for this preprint (which was not certified by peer review) is the author/funder, who has granted medRxiv a license to display the preprint in perpetuity.

All rights reserved. No reuse allowed without permission.

GFATadjBMI were 1.17 (95\% Cl 1.11-1.22), 1.00 (95\% Cl 0.94-1.05), and 0.89 (95\% $\mathrm{Cl} 0.84-0.94)$, respectively.

To better understand the gradients in absolute prevalence rates according to BMI-adjusted fat depots, we calculated standardized estimates for the lowest quintile, quintiles $2-4$, and the highest quintile within clinical categories of normal, overweight, and obese participants.

Using this approach, we note substantial gradients in the prevalence of cardiometabolic diseases according to local adipose tissue burden, even within clinical BMI categories (Figure 4, Table S6-S7). As a representative example, men with normal BMI but VATadjBMI in the highest quintile had a probability of type 2 diabetes of $6.6 \%(95 \% \mathrm{Cl} 5.5-7.9)$, higher than obese men with VATadjBMI in the lowest quintile, in whom probability was $5.2 \%(95 \% \mathrm{Cl} 4.1-6.6)$. Among obese women, estimates of diabetes ranged from 3.5 to $9.2 \%$ across quintiles of VATadjBMI but 7.6 to $3.6 \%$ for GFATadjBMI. A similar pattern - with less pronounced gradients - was observed for coronary artery disease.

BMI-adjusted fat depots and risk of incident cardiometabolic diseases

Over a median follow-up of 1.8 years, $169(0.4 \%)$ and $405(1.0 \%)$ participants had a new diagnosis of type 2 diabetes or coronary artery disease recorded in the electronic health record. BMI-adjusted fat depots were similarly associated with risk of future disease events in mutually adjusted models. For incident type 2 diabetes, hazard ratios per SD increase (HR/SD) were $1.45(95 \% \mathrm{Cl} 1.28-1.65), 0.96(95 \% \mathrm{Cl}$ 0.83-1.11), and 0.85 (95\% Cl 0.74-0.99) for VATadjBMI, ASATadjBMI, and GFATadjBMI, respectively (Table S8). For incident coronary artery disease, HR/SD were $1.18(95 \% \mathrm{Cl} 1.07-1.30), 1.02$ (95\% $\mathrm{Cl} 0.91-$ 1.14), and 0.93 (95\% $\mathrm{Cl} 0.83-1.04)$ for VATadjBMI, ASATadjBMI, and GFATadjBMI, respectively. 
medRxiv preprint doi: https://doi.org/10.1101/2021.05.07.21256854; this version posted May 10, 2021. The copyright holder for this preprint (which was not certified by peer review) is the author/funder, who has granted medRxiv a license to display the preprint in perpetuity.

All rights reserved. No reuse allowed without permission.

\section{DISCUSSION}

In this study, we used a machine learning-based approach to quantify VAT, ASAT, and GFAT depot volumes from MRI images of 40,032 individuals. By then moving away from raw fat depot volumes which are driven largely by BMI and overall adiposity - to BMI-adjusted measurements, we demonstrated a consistent trend of VATadjBMI associated with increasing risk of type 2 diabetes and coronary artery disease, ASATadjBMI largely risk-neutral, and GFATadjBMI conferring protection.

These results have at least three implications. First, machine learning can enable new insights from large-scale data repositories of difficult-to-measure phenotypes. In this study, convolutional neural network models were used to precisely measure fat depot measurements from MRI images, considered the gold standard modality for volumetric measurement of adipose tissue. ${ }^{16,32}$ This work adds to several recent studies of machine learning-derived phenotypes including aortic size, liver fat, cardiac trabecular structure, and features of screening mammogram images most predictive of breast cancer. ${ }^{33-36}$ Although population-based assessment of fat distribution using MRI is unlikely to be practical, these results lay the scientific foundation for efforts to quantify such measures using other data - such as DEXA images or abdominal CT scans already embedded in the electronic medical record for some patients - or even static images of body silhouette, as might conceivably be obtained with a smartphone camera..$^{37,38}$

Second, these results support a growing appreciation that various fat depots - rather than serving as an agnostic sink for energy storage - have distinct metabolic profiles. Previous work has noted significant functional differences in adipocytes according to specific fat depot, ascribed in part to sitespecific expression of developmental genes associated with adipogenesis. ${ }^{39,40}$ While VAT tends to be the primary site for immediate storage of dietary-derived fat via adipocyte hypertrophy and has a higher rate of lipid turnover, GFAT is a more stable fat depot that primarily expands via adipocyte hyperplasia and may spare expansion of harmful visceral or ectopic fat depots. These and other studies support a 
medRxiv preprint doi: https://doi.org/10.1101/2021.05.07.21256854; this version posted May 10, 2021. The copyright holder for this preprint (which was not certified by peer review) is the author/funder, who has granted medRxiv a license to display the preprint in perpetuity. All rights reserved. No reuse allowed without permission.

natural order of fat deposition, whereby a primary driver of high VAT in specific individuals may reflect an inability to adequately expand ASAT or GFAT depots. ${ }^{13,41}$ In rare Mendelian lipodystrophies - as occurs in individuals who harbor pathogenic LMNA mutations - an extreme example of this paradigm leads to marked reduction of ASAT and GFAT but relatively increased VAT and increased rates of severe insulin resistance. ${ }^{42}$ Whether individuals in the extreme tails of low GFATadjBMI and ASATadjBMI or high VATadjBMI might be enriched for genetic perturbations in lipodystrophy genes or the inherited component to these metrics is largely 'polygenic' - due to the aggregate effects of many common DNA variants, each of modest effect size - warrants further study. ${ }^{43,44}$

Third, changes in measures of local adiposity - independent of weight and body-mass index - may serve as reliable proxies of cardiometabolic benefits of a given intervention, and warrant consideration as additional endpoints for future clinical trials. Most studies to date of obesity interventions have focused on reduction in overall weight or BMI as the primary outcome, consistent with FDA regulatory guidance. ${ }^{45}$ However, at least two classes of drugs appear to have a selective VAT reduction effect in clinical trials: thiazolidinediones and a synthetic form of growth hormone releasing hormone. ${ }^{46,47}$ Whether these therapies might be repurposed from their original indications - type 2 diabetes and HIVassociated lipodystrophy - or new agents might prove useful in a subset of individuals with VAT-driven increases in cardiometabolic risk warrants further study.

Our study has several limitations. First, the majority of UK Biobank participants are white. Additional efforts are needed to extend these results to geographically and ancestrally diverse populations. ${ }^{48}$ Second, this study was a cross-sectional analysis of individuals with mean age of 65 years at time of imaging. Future studies of individuals across the lifespan - especially those that include repeat imaging assessments - are warranted. Third, although we note striking associations of BMI-adjusted fat depots with cardiometabolic disease these observational data do not definitely prove causation or ability to modify fat distribution for therapeutic gain. 
medRxiv preprint doi: https://doi.org/10.1101/2021.05.07.21256854; this version posted May 10, 2021. The copyright holder for this preprint (which was not certified by peer review) is the author/funder, who has granted medRxiv a license to display the preprint in perpetuity. All rights reserved. No reuse allowed without permission.

In conclusion, our machine-learning based analysis of raw MRI imaging data of 40,032 UK Blobank participants confirms prior observations of marked variation in fat distribution among participants with a given BMI. We extend these prior results by generating BMI-adjusted measures of local adiposity burden that have variable and divergent associations with important cardiometabolic diseases. 
medRxiv preprint doi: https://doi.org/10.1101/2021.05.07.21256854; this version posted May 10, 2021. The copyright holder for this preprint (which was not certified by peer review) is the author/funder, who has granted medRxiv a license to display the preprint in perpetuity.

All rights reserved. No reuse allowed without permission.

\section{ACKNOWLEDGEMENTS}

The authors thank Mary O'Reilly of the Broad Institute's Pattern data visualization team for assistance in graphic and visual design.

\section{Sources of Funding}

This work was supported by the Sarnoff Cardiovascular Research Foundation Fellowship (to S.A.), grant 1K08HG010155 (to A.V.K.) from the National Human Genome Research Institute, a Hassenfeld Scholar Award from Massachusetts General Hospital (to A.V.K.), a Merkin Institute Fellowship from the Broad Institute of MIT and Harvard (to A.V.K.), and a sponsored research agreement from IBM Research to the Broad Institute of MIT and Harvard (P.T.E., A.P., P.B., A.V.K.).

\section{Author Disclosures}

M.D.R.K., N.D., A.P, and P.B. are supported by grants from Bayer AG applying machine learning in cardiovascular disease. P.T.E. receives sponsored research support from Bayer AG and IBM and has consulted for Bayer AG, Novartis, MyoKardia and Quest Diagnostics. A.P. is also employed as a Venture Partner at GV and consulted for Novartis; and has received funding from Intel, Verily and MSFT. K.N. is an employee of IBM Research. P.B serves as a consultant for Novartis. A.V.K. has served as a scientific advisor to Sanofi, Medicines Company, Maze Therapeutics, Navitor Pharmaceuticals, Sarepta Therapeutics, Verve Therapeutics, Amgen, Color, and Columbia University (NIH); received speaking fees from Illumina, MedGenome, Amgen, and the Novartis Institute for Biomedical Research; and received a sponsored research agreement from the Novartis Institute for Biomedical Research. 
medRxiv preprint doi: https://doi.org/10.1101/2021.05.07.21256854; this version posted May 10, 2021. The copyright holder for this preprint (which was not certified by peer review) is the author/funder, who has granted medRxiv a license to display the preprint in perpetuity. All rights reserved. No reuse allowed without permission.

\section{REFERENCES}

1. Kivimäki M, Kuosma E, Ferrie JE, et al. Overweight, obesity, and risk of cardiometabolic multimorbidity: pooled analysis of individual-level data for 120 [13 adults from 16 cohort studies from the USA and Europe. Lancet Public Health 2017;2(6):e277-85.

2. Calle EE. Overweight, Obesity, and Mortality from Cancer in a Prospectively Studied Cohort of U.S. Adults. N Engl J Med 2003;14.

3. Anderson MR, Geleris J, Anderson DR, et al. Body Mass Index and Risk for Intubation or Death in SARS-CoV-2 Infection?]: A Retrospective Cohort Study. Ann Intern Med 2020;173(10):782-90.

4. González-Muniesa P, Mártinez-González M-A, Hu FB, et al. Obesity. Nat Rev Dis Primer 2017;3(1):1-18.

5. Ward ZJ, Bleich SN, Cradock AL, et al. Projected U.S. State-Level Prevalence of Adult Obesity and Severe Obesity. N Engl J Med 2019;381(25):2440-50.

6. Karelis AD, St-Pierre DH, Conus F, Rabasa-Lhoret R, Poehlman ET. Metabolic and Body Composition Factors in Subgroups of Obesity: What Do We Know? J Clin Endocrinol Metab 2004;89(6):2569-75.

7. McLaughlin T, Abbasi F, Lamendola C, Reaven G. Heterogeneity in the prevalence of risk factors for cardiovascular disease and type 2 diabetes mellitus in obese individuals: effect of differences in insulin sensitivity. Arch Intern Med 2007;167(7):642-8.

8. Wildman RP, Muntner P, Reynolds K, et al. The obese without cardiometabolic risk factor clustering and the normal weight with cardiometabolic risk factor clustering: prevalence and correlates of 2 phenotypes among the US population (NHANES 1999-2004). Arch Intern Med 2008;168(15):1617-24.

9. Mathew H, Farr OM, Mantzoros CS. Metabolic health and weight: Understanding metabolically unhealthy normal weight or metabolically healthy obese patients. Metabolism 2016;65(1):73-80.

10. Lotta LA, Abbasi A, Sharp SJ, et al. Definitions of Metabolic Health and Risk of Future Type 2 
medRxiv preprint doi: https://doi.org/10.1101/2021.05.07.21256854; this version posted May 10, 2021. The copyright holder for this preprint (which was not certified by peer review) is the author/funder, who has granted medRxiv a license to display the preprint in perpetuity.

All rights reserved. No reuse allowed without permission.

Diabetes in BMI Categories: A Systematic Review and Network Meta-analysis. Diabetes Care 2015;38(11):2177-87.

11. Ross R, Neeland IJ, Yamashita S, et al. Waist circumference as a vital sign in clinical practice: a Consensus Statement from the IAS and ICCR Working Group on Visceral Obesity. Nat Rev Endocrinol 2020;16(3):177-89.

12. Stefan N, Schick F, Häring H-U. Causes, Characteristics, and Consequences of Metabolically Unhealthy Normal Weight in Humans. Cell Metab 2017;26(2):292-300.

13. Stefan N. Causes, consequences, and treatment of metabolically unhealthy fat distribution. Lancet Diabetes Endocrinol 2020;8(7):616-27.

14. Ashwell M, Cole TJ, Dixon AK. Obesity: new insight into the anthropometric classification of fat distribution shown by computed tomography. Br Med J Clin Res Ed 1985;290(6483):1692-4.

15. Tchernof A, Després J-P. Pathophysiology of Human Visceral Obesity: An Update. Physiol Rev 2013;93(1):359-404.

16. Neeland IJ, Ross R, Després J-P, et al. Visceral and ectopic fat, atherosclerosis, and cardiometabolic disease: a position statement. Lancet Diabetes Endocrinol 2019;7(9):715-25.

17. Stefan N, Kantartzis K, Machann J, et al. Identification and characterization of metabolically benign obesity in humans. Arch Intern Med 2008;168(15):1609-16.

18. Neeland IJ, Ayers CR, Rohatgi AK, et al. Associations of visceral and abdominal subcutaneous adipose tissue with markers of cardiac and metabolic risk in obese adults. Obesity 2013;21(9):E439-47.

19. Neeland IJ, Turer AT, Ayers CR, et al. Body Fat Distribution and Incident Cardiovascular Disease in Obese Adults. J Am Coll Cardiol 2015;65(19):2150-1.

20. Linge J, Borga M, West J, et al. Body Composition Profiling in the UK Biobank Imaging Study. Obes Silver Spring Md 2018;26(11):1785-95. 
medRxiv preprint doi: https://doi.org/10.1101/2021.05.07.21256854; this version posted May 10, 2021. The copyright holder for this preprint (which was not certified by peer review) is the author/funder, who has granted medRxiv a license to display the preprint in perpetuity. All rights reserved. No reuse allowed without permission.

21. Linge J, Whitcher B, Borga M, Dahlqvist Leinhard O. Sub-phenotyping Metabolic Disorders Using Body Composition: An Individualized, Nonparametric Approach Utilizing Large Data Sets. Obes Silver Spring Md 2019;27(7):1190-9.

22. Manolopoulos KN, Karpe F, Frayn KN. Gluteofemoral body fat as a determinant of metabolic health. Int J Obes 2005 2010;34(6):949-59.

23. Janssen I, Heymsfield SB, Allison DB, Kotler DP, Ross R. Body mass index and waist circumference independently contribute to the prediction of nonabdominal, abdominal subcutaneous, and visceral fat. Am J Clin Nutr 2002;75(4):683-8.

24. Sudlow C, Gallacher J, Allen N, et al. UK biobank: an open access resource for identifying the causes of a wide range of complex diseases of middle and old age. PLoS Med 2015;12(3):e1001779.

25. Littlejohns TJ, Holliday J, Gibson LM, et al. The UK Biobank imaging enhancement of 100,000 participants: rationale, data collection, management and future directions. Nat Commun 2020;11(1):2624.

26. West J, Leinhard OD, Romu T, et al. Feasibility of MR-Based Body Composition Analysis in Large Scale Population Studies. PLOS ONE 2016;11(9):e0163332.

27. Borga M, West J, Bell JD, et al. Advanced body composition assessment: from body mass index to body composition profiling. J Investig Med Off Publ Am Fed Clin Res 2018;66(5):1-9.

28. Shungin D, Winkler TW, Croteau-Chonka DC, et al. New genetic loci link adipose and insulin biology to body fat distribution. Nature 2015;518(7538):187-96.

29. Emdin CA, Khera AV, Natarajan P, et al. Genetic Association of Waist-to-Hip Ratio With Cardiometabolic Traits, Type 2 Diabetes, and Coronary Heart Disease. JAMA 2017;317(6):626-34.

30. Pou KM, Massaro JM, Hoffmann U, et al. Patterns of Abdominal Fat Distribution: The Framingham Heart Study. Diabetes Care 2009;32(3):481-5. 
medRxiv preprint doi: https://doi.org/10.1101/2021.05.07.21256854; this version posted May 10, 2021. The copyright holder for this preprint (which was not certified by peer review) is the author/funder, who has granted medRxiv a license to display the preprint in perpetuity.

All rights reserved. No reuse allowed without permission.

31. Hiuge-Shimizu A, Kishida K, Funahashi $\mathrm{T}$, et al. Absolute value of visceral fat area measured on computed tomography scans and obesity-related cardiovascular risk factors in large-scale Japanese general population (the VACATION-J study). Ann Med 2012;44(1):82-92.

32. Deo RC. Machine Learning in Medicine. Circulation 2015;132(20):1920-30.

33. Pirruccello JP, Chaffin MD, Fleming SJ, et al. Deep learning enables genetic analysis of the human thoracic aorta. bioRxiv 2020;2020.05.12.091934.

34. Haas ME, Pirruccello JP, Friedman SN, et al. Machine learning enables new insights into clinical significance of and genetic contributions to liver fat accumulation. medRxiv 2020;2020.09.03.20187195.

35. Meyer HV, Dawes TJW, Serrani M, et al. Genetic and functional insights into the fractal structure of the heart. Nature 2020;584(7822):589-94.

36. McKinney SM, Sieniek M, Godbole V, et al. International evaluation of an Al system for breast cancer screening. Nature 2020;577(7788):89-94.

37. Larson DB, Johnson LW, Schnell BM, Salisbury SR, Forman HP. National Trends in CT Use in the Emergency Department: 1995-2007. Radiology 2011;258(1):164-73.

38. Hu P, Kaashki NN, Dadarlat V, Munteanu A. Learning to Estimate the Body Shape Under Clothing From a Single 3-D Scan. IEEE Trans Ind Inform 2021;17(6):3793-802.

39. Gesta S, Blüher M, Yamamoto Y, et al. Evidence for a role of developmental genes in the origin of obesity and body fat distribution. Proc Natl Acad Sci U S A 2006;103(17):6676-81.

40. Karpe F, Pinnick KE. Biology of upper-body and lower-body adipose tissue-link to whole-body phenotypes. Nat Rev Endocrinol 2015;11(2):90-100.

41. Després J-P, Lemieux I. Abdominal obesity and metabolic syndrome. Nature 2006;444(7121):8817.

42. Shackleton S, Lloyd DJ, Jackson SN, et al. LMNA, encoding lamin A/C, is mutated in partial 
medRxiv preprint doi: https://doi.org/10.1101/2021.05.07.21256854; this version posted May 10, 2021. The copyright holder for this preprint

(which was not certified by peer review) is the author/funder, who has granted medRxiv a license to display the preprint in perpetuity.

All rights reserved. No reuse allowed without permission.

lipodystrophy. Nat Genet 2000;24(2):153-6.

43. Karlsson $\mathrm{T}$, Rask-Andersen $\mathrm{M}, \mathrm{Pan} \mathrm{G}$, et al. Contribution of genetics to visceral adiposity and its relation to cardiovascular and metabolic disease. Nat Med 2019;25(9):1390-5.

44. Lotta LA, Gulati P, Day FR, et al. Integrative genomic analysis implicates limited peripheral adipose storage capacity in the pathogenesis of human insulin resistance. Nat Genet 2017;49(1):17-26.

45. Colman E. Food and Drug Administration's Obesity Drug Guidance Document: A Short History. Circulation 2012;125(17):2156-64.

46. Kodama N, Tahara N, Tahara A, et al. Effects of Pioglitazone on Visceral Fat Metabolic Activity in Impaired Glucose Tolerance or Type 2 Diabetes Mellitus. J Clin Endocrinol Metab 2013;98(11):4438-45.

47. Stanley TL, Feldpausch MN, Oh J, et al. Effect of tesamorelin on visceral fat and liver fat in HIVinfected patients with abdominal fat accumulation: a randomized clinical trial. JAMA 2014;312(4):380-9.

48. Shah Ravi V., Murthy Venkatesh L., Abbasi Siddique A., et al. Visceral Adiposity and the Risk of Metabolic Syndrome Across Body Mass Index. JACC Cardiovasc Imaging 2014;7(12):1221-35. 
medRxiv preprint doi: https://doi.org/10.1101/2021.05.07.21256854; this version posted May 10, 2021. The copyright holder for this preprint (which was not certified by peer review) is the author/funder, who has granted medRxiv a license to display the preprint in perpetuity.

All rights reserved. No reuse allowed without permission.

FIGURE LEGENDS

FIGURE 1 Convolutional neural networks to quantify adipose tissue depots from body MRI images
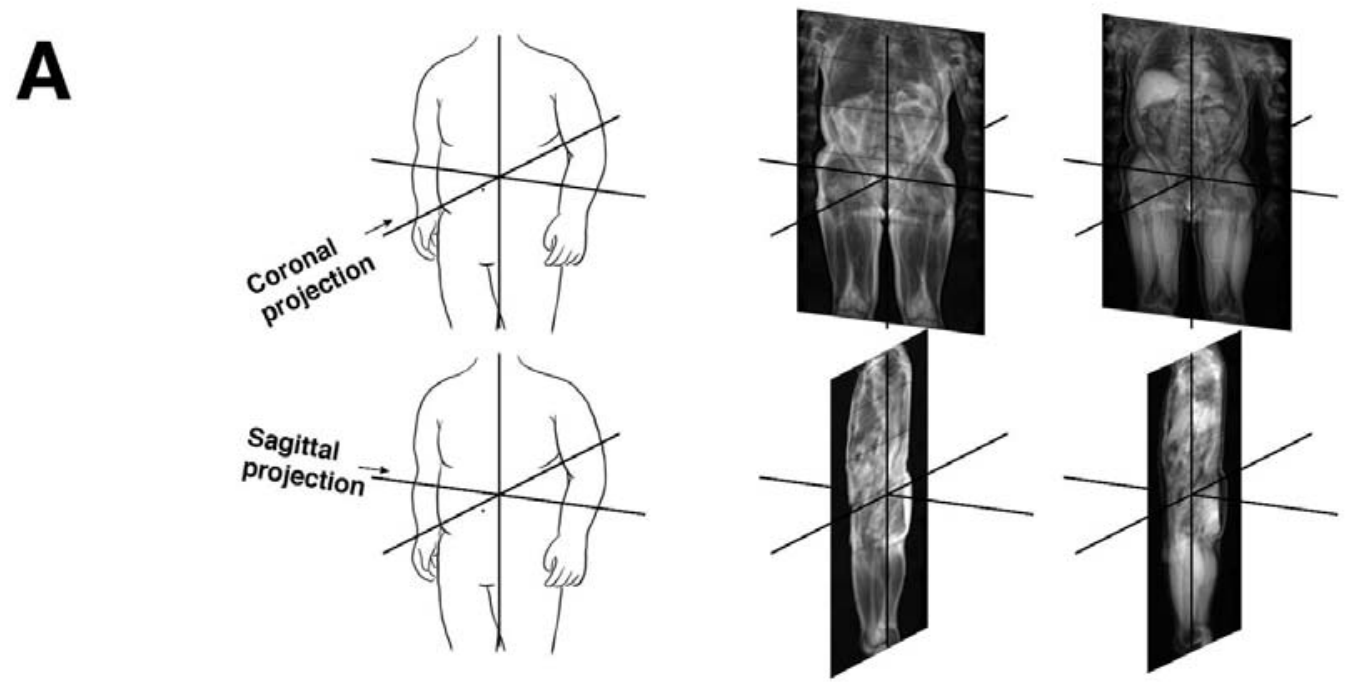

Fat phase

Water phase

B
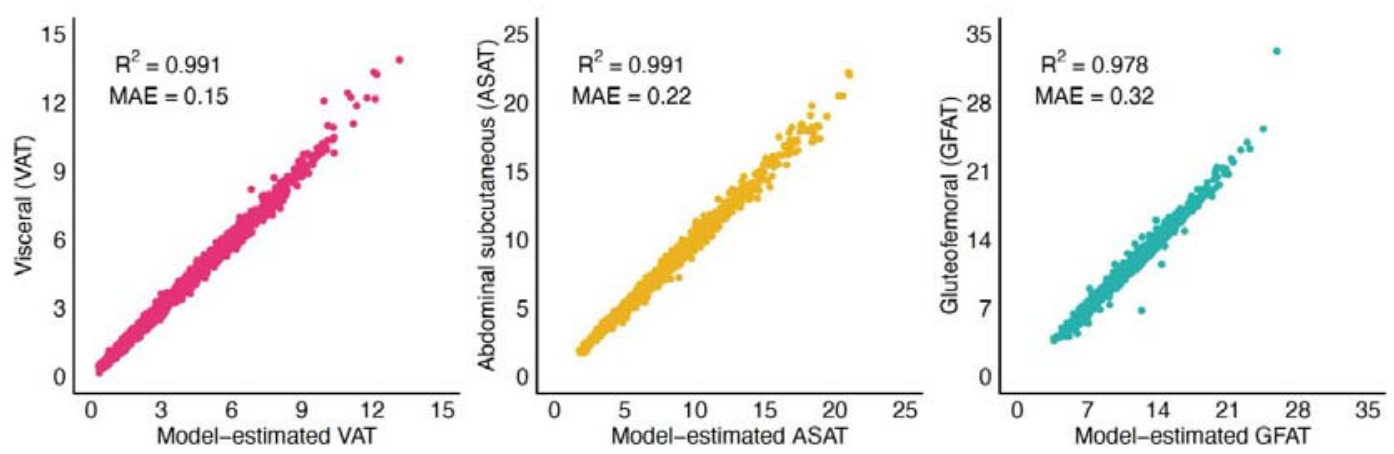

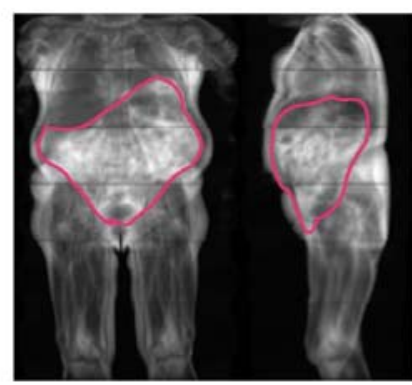

VAT: 8.1 L (99th percentile) ASAT: $8.3 \mathrm{~L}$ (41st percentile) GFAT: $10.6 \mathrm{~L}$ (27th percentile)

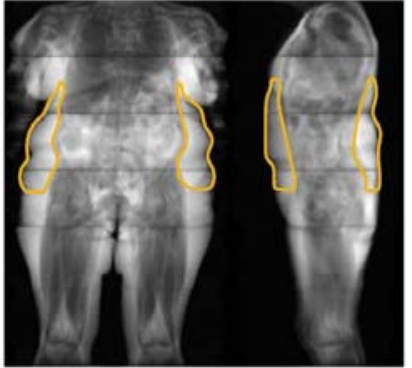

VAT: $4.3 \mathrm{~L}$ (88th percentile) ASAT: $16.1 \mathrm{~L}$ (99th percentile) GFAT: 14.8 L (91st percentile)

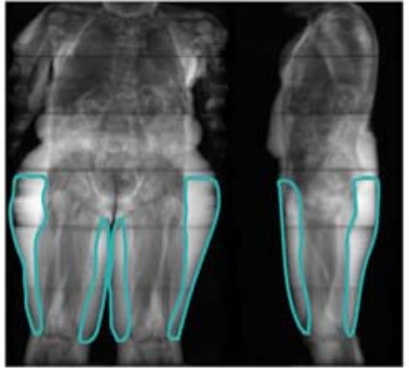

VAT: $2.2 \mathrm{~L}$ (25th percentile) ASAT: $9.2 \mathrm{~L}$ (64th percentile) GFAT: 19.7 L (99th percentile) 
medRxiv preprint doi: https://doi.org/10.1101/2021.05.07.21256854; this version posted May 10, 2021. The copyright holder for this preprint (which was not certified by peer review) is the author/funder, who has granted medRxiv a license to display the preprint in perpetuity.

All rights reserved. No reuse allowed without permission.

(A) Two-dimensional projections are created by computing the mean pixel intensity along the coronal and sagittal axes. Two images were used as inputs into the convolutional neural network (CNN): one consisting of the coronal and sagittal two-dimensional projections in the fat phase, and another consisting of the same projections in the water phase. (B) CNNs trained on two-dimensional MRI projections achieved near-perfect prediction of each fat depot volume as measured by $R^{2}$ and mean absolute error (MAE) in the holdout set (Table S1). (C) Three female participants with similar BMI (ranging from 29.1 to $29.6 \mathrm{~kg} / \mathrm{m}^{2}$ ) but highly discordant fat depot volumes quantified by CNNs. Fat depot volume percentiles are computed relative to a subgroup of women with overweight $\mathrm{BMI}(25 \leq \mathrm{BMI}<$ 30). Abbreviations: VAT, visceral adipose tissue; ASAT, abdominal subcutaneous adipose tissue; GFAT, gluteofemoral adipose tissue. 
medRxiv preprint doi: https://doi.org/10.1101/2021.05.07.21256854; this version posted May 10, 2021. The copyright holder for this preprint (which was not certified by peer review) is the author/funder, who has granted medRxiv a license to display the preprint in perpetuity.

All rights reserved. No reuse allowed without permission.

FIGURE 2 Sex-stratified density plots and correlation plots of visceral, abdominal subcutaneous, and gluteofemoral adipose tissue volumes
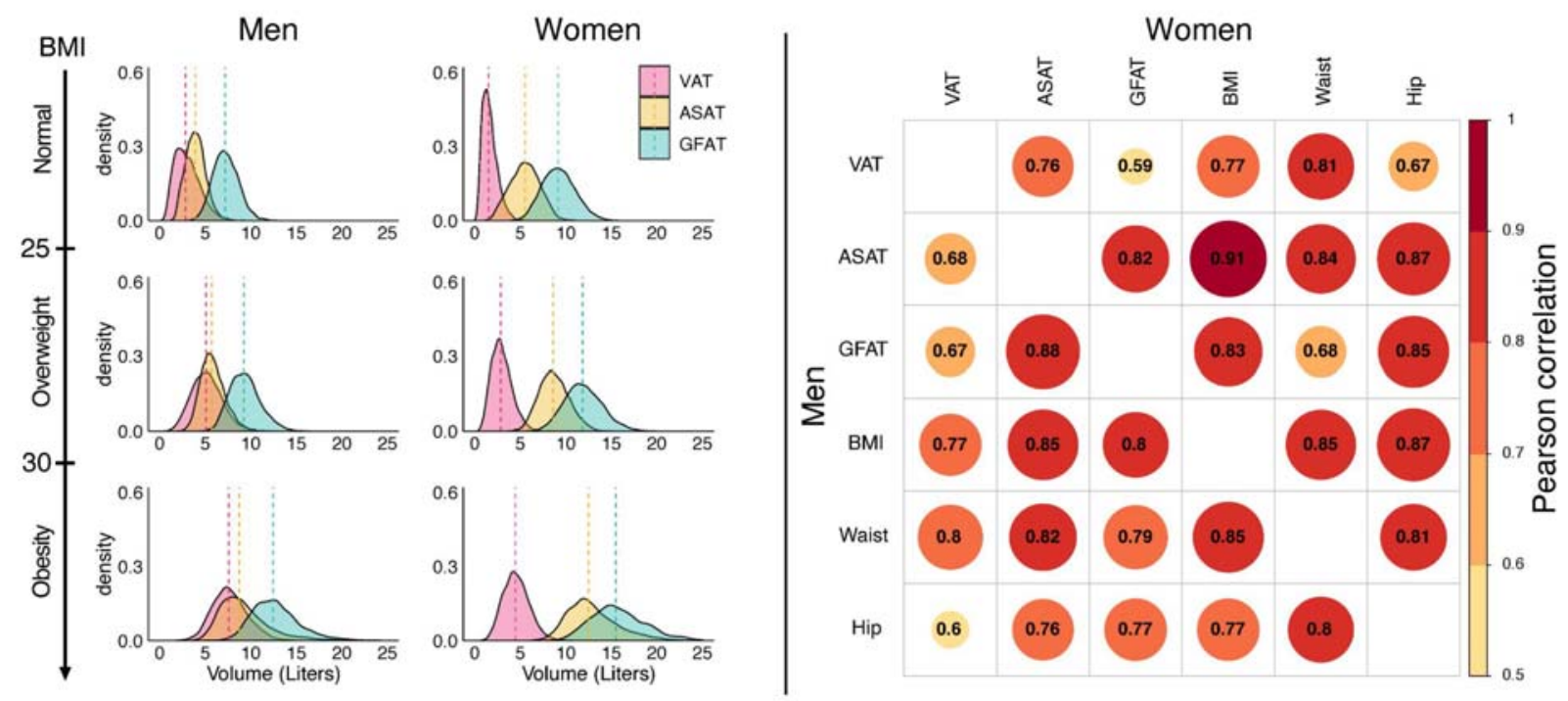

(A; left) Sex- and BMI-group specific density plots for visceral adipose tissue (VAT), abdominal subcutaneous adipose tissue (ASAT), and gluteofemoral adipose tissue (GFAT). (B; right) Sex-stratified correlation plots between VAT, ASAT, GFAT and three anthropometric measures: body mass index (BMI), waist circumference (Waist), and hip circumference (Hip). Similar plots for BMI-adjusted fat depots are shown in Figure S2-S3. 
medRxiv preprint doi: https://doi.org/10.1101/2021.05.07.21256854; this version posted May 10, 2021. The copyright holder for this preprint (which was not certified by peer review) is the author/funder, who has granted medRxiv a license to display the preprint in perpetuity. All rights reserved. No reuse allowed without permission.

FIGURE 3 Association of body-mass index adjusted fat depots with type 2 diabetes and coronary artery disease

\section{Type 2 Diabetes}

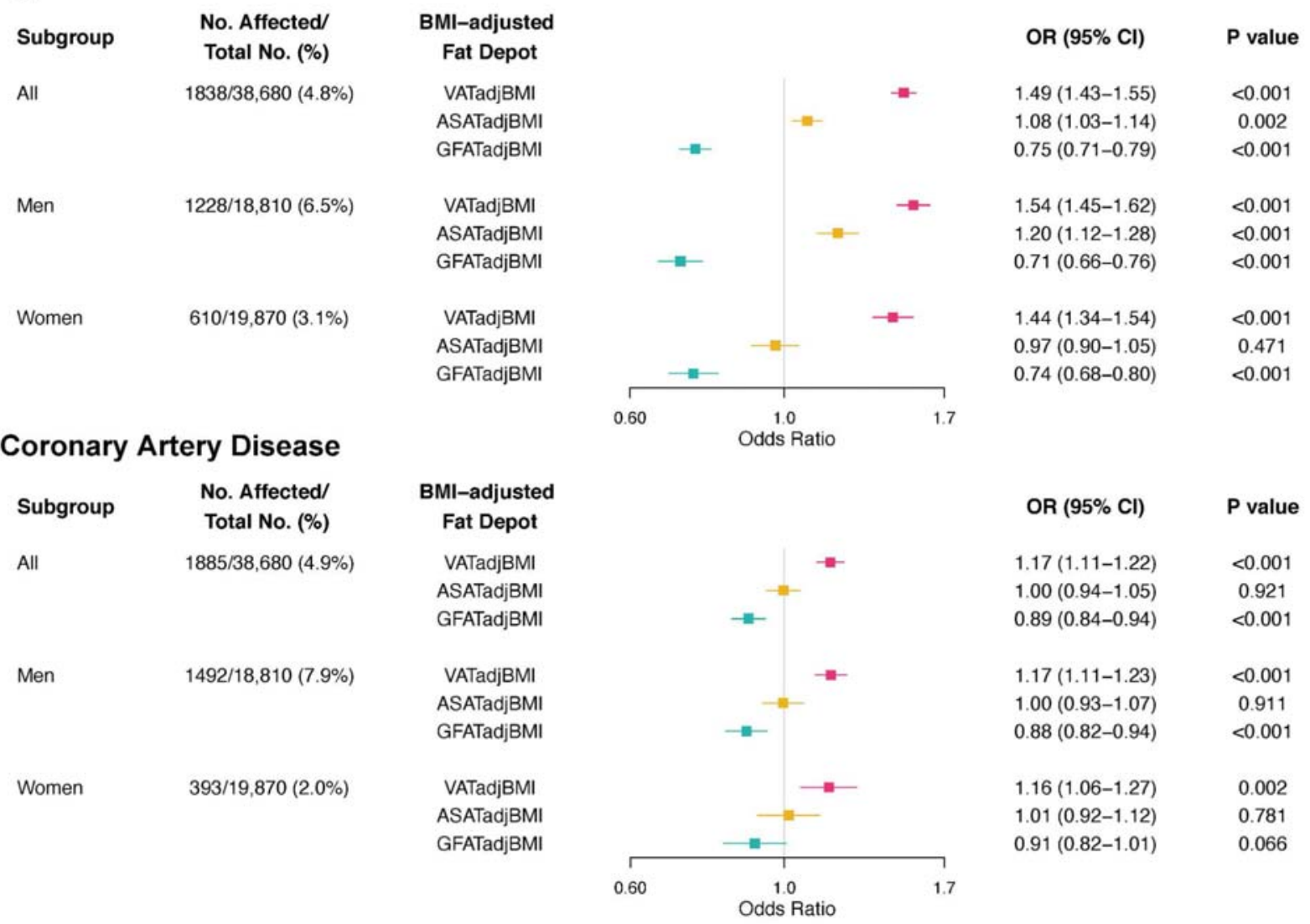

(A; top) Odds ratios per standard deviation shown for prevalent type 2 diabetes. (B; bottom) Odds ratios per standard deviation shown for prevalent coronary artery disease. Logistic regression models were adjusted for age, sex (excluding sex subgroup analyses), BMI, the other two fat depots (e.g. ASATadjBMI and GFATadjBMI for VATadjBMI), and MRI imaging center. 
medRxiv preprint doi: https://doi.org/10.1101/2021.05.07.21256854; this version posted May 10, 2021. The copyright holder for this preprint (which was not certified by peer review) is the author/funder, who has granted medRxiv a license to display the preprint in perpetuity. All rights reserved. No reuse allowed without permission.

FIGURE 4 Prevalence of type 2 diabetes and coronary artery disease, according to quintiles of body-mass index adjusted fat depot and body-mass index strata
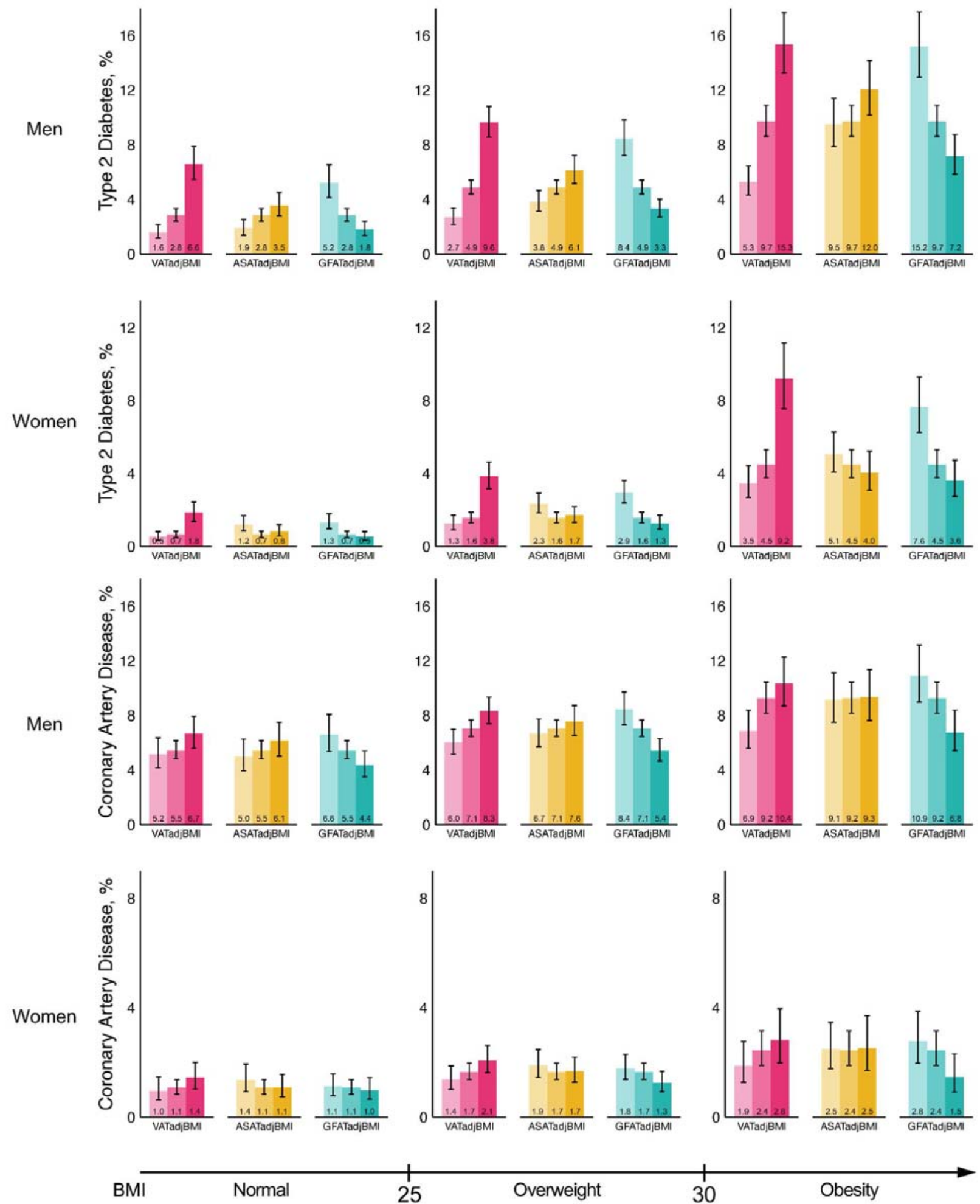

25

Overweight

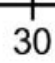

Obesity 
medRxiv preprint doi: https://doi.org/10.1101/2021.05.07.21256854; this version posted May 10, 2021. The copyright holder for this preprint (which was not certified by peer review) is the author/funder, who has granted medRxiv a license to display the preprint in perpetuity. All rights reserved. No reuse allowed without permission.

For each fat depot, the three bars from lightest to darkest represent the bottom quintile, quintiles 2-4, and the top quintile of the BMI-adjusted fat depot in question, respectively. Mean body-mass index was $26.5 \mathrm{~kg} / \mathrm{m}^{2}$ with 15,446 (39.9\%) individuals with $\mathrm{BMI}<25,16,179(41.8 \%)$ with $25 \leq \mathrm{BMI}<30$, and 7055 (18.2\%) with $\mathrm{BMI} \geq 30$. 
medRxiv preprint doi: https://doi.org/10.1101/2021.05.07.21256854; this version posted May 10, 2021. The copyright holder for this preprint (which was not certified by peer review) is the author/funder, who has granted medRxiv a license to display the preprint in perpetuity.

All rights reserved. No reuse allowed without permission.

\section{TABLES}

TABLE 1 Baseline characteristics of UK Biobank participants at the time of MRI imaging

\begin{tabular}{|c|c|c|}
\hline & $\begin{array}{c}\text { Women } \\
(N=20,597)\end{array}$ & $\begin{array}{c}\text { Men } \\
(N=19,435)\end{array}$ \\
\hline Age (years) & $63.8 \pm 7.5$ & $65.2 \pm 7.7$ \\
\hline \multicolumn{3}{|l|}{ Race } \\
\hline White & $19,936(96.8)$ & $18,773(96.6)$ \\
\hline Black & $192(0.9)$ & $137(0.7)$ \\
\hline East Asian & $137(0.7)$ & $112(0.6)$ \\
\hline South Asian & $133(0.6)$ & $238(1.2)$ \\
\hline Other & $199(1.0)$ & $175(0.9)$ \\
\hline $\begin{array}{l}\text { Systolic blood pressure } \\
\text { (mmHg) }\end{array}$ & $135.8 \pm 19.2$ & $142.0 \pm 17.4$ \\
\hline $\begin{array}{l}\text { Diastolic blood pressure } \\
\text { (mmHg) }\end{array}$ & $76.7 \pm 10.0$ & $80.6 \pm 9.9$ \\
\hline Current smoker & $583(2.9)$ & $785(4.1)$ \\
\hline Weight (lbs) & $151.8 \pm 28.0$ & $184.8 \pm 29.0$ \\
\hline Height (in) & $64.1 \pm 2.5$ & $69.4 \pm 2.6$ \\
\hline
\end{tabular}


medRxiv preprint doi: https://doi.org/10.1101/2021.05.07.21256854; this version posted May 10, 2021. The copyright holder for this preprint (which was not certified by peer review) is the author/funder, who has granted medRxiv a license to display the preprint in perpetuity.

All rights reserved. No reuse allowed without permission.

\begin{tabular}{|c|c|c|}
\hline Body-mass index $\left(\mathrm{kg} / \mathrm{m}^{2}\right)$ & $26.1 \pm 4.6$ & $27.1 \pm 3.8$ \\
\hline Waist circumference $(\mathrm{cm})$ & $82.8 \pm 11.6$ & $94.6 \pm 10.5$ \\
\hline Hip circumference (cm) & $100.9 \pm 9.6$ & $100.9 \pm 7.3$ \\
\hline Waist-to-hip ratio & $0.82 \pm 0.07$ & $0.94 \pm 0.06$ \\
\hline \multicolumn{3}{|l|}{ Fat Depot Volumes } \\
\hline Visceral adipose tissue (L) & $2.6 \pm 1.5$ & $5.0 \pm 2.3$ \\
\hline $\begin{array}{l}\text { Abdominal subcutaneous } \\
\text { adipose tissue (L) }\end{array}$ & $7.9 \pm 3.3$ & $5.9 \pm 2.5$ \\
\hline $\begin{array}{l}\text { Gluteofemoral adipose tissue } \\
\text { (L) }\end{array}$ & $11.3 \pm 3.2$ & $9.3 \pm 2.6$ \\
\hline \multicolumn{3}{|l|}{ Cardiometabolic diseases } \\
\hline Type 2 diabetes & $637(3.1)$ & $1,264(6.5)$ \\
\hline Coronary artery disease & $414(2.0)$ & $1542(7.9)$ \\
\hline
\end{tabular}

Plus-minus values are means \pm SD. Race was determined on the basis of self-reported ethnic background at time of enrollment in the UK Biobank. 